\title{
Identification and Mapping of QTLS for Drought Resistance in Rice
}

\author{
Helan Baby Thomas*, Thriveni Vangapandu, Bharathi Ayyenar and Reena Sellamuthu \\ Centre for Plant Molecular Biology and Biotechnology, Coimbatore, Tamil Nadu, India \\ *Corresponding author
}

\begin{tabular}{|c|c|}
\hline & A B S T R A C T \\
\hline & \multirow{6}{*}{$\begin{array}{l}\text { Rice (Oryza sativa L.) is one of the most important staple foods for more than half } \\
\text { the world's population and influences the livelihoods and economies of several } \\
\text { billion people. Drought stress is the major constraint to rice production and yield } \\
\text { stability in rainfed ecosystems. Efforts have been made to identify putative traits, } \\
\text { which can confer drought resistance in rice grown under rainfed lowland. } \\
\text { However, little progress has been made in incorporating tolerance to abiotic } \\
\text { stresses such as drought, since the fundamental mechanisms of drought resistance } \\
\text { in rice are poorly understood. Efforts have been made for identifying putative } \\
\text { traits encoding different drought resistance traits. The results are being used in } \\
\text { marker assisted selection (MAS) for the development of drought resistant } \\
\text { varieties. Recent trends in climate change have predicted a further increase in } \\
\text { drought intensity, making the development of new drought-tolerant rice cultivars } \\
\text { critical to sustain rice production in this ecosystem. }\end{array}$} \\
\hline Keywords & \\
\hline $\begin{array}{l}\text { Rice, } \\
\text { Drought, } \\
\text { QTL, Resistance. }\end{array}$ & \\
\hline Article Info & \\
\hline $\begin{array}{l}\text { Accepted: } \\
\text { 19 June } 2017 \\
\text { Available Online: } \\
\text { 10 July } 2017\end{array}$ & \\
\hline & \\
\hline
\end{tabular}

\section{Introduction}

Rice has been feeding the world for over 4000 years and is the staple food of about 557 million people (Manzanilla et al., 2011). In 2016-17, the average annual consumption per capita in India was about 102.72 million tonnes (Rice Commodity Profile, 2017). According to IRRI (2000) the global rice production should increase by 800 million tonnes by 2025 in order to feed the growing population. As a semi-aquatic crop, rice faces various abiotic stresses among which, drought is the most prominent.

Drought is a major limitation for rice production in rainfed ecosystems (Kamoshita et al., 2008). Millions of hectares of lowland rainfed rice areas are affected by drought in years with very low rainfall and it reduces rice productivity by $13-35 \%$ (Jongde, 1998.) The drought vulnerability scenarios are likely to worsen in the future with predicted climate change scenarios, which will also lead to more complex interactions of drought with other abiotic and biotic stresses (Wasmann et al., 2009).

Despite drought having been a focus of agricultural research for several decades, progress in delivering drought adapted rice varieties and technologies has been relatively slow as the genetic mechanisms behind drought tolerance is still merely understood. The various methods used for developing a drought tolerant variety are listed in figure 1 . 


\section{Effect of drought on rice}

The effect of drought in rice varies with the variety, degree and duration of stress and its coincidence with different growth stages (Lanceras et al., 2004). Water deficit at the vegetative stage seems to be the least detrimental to yield (Chang et al., 1982).Water deficit at the reproductive stage is most damaging to rice yield (O'Toole, 1982). Grain yield is affected, particularly when drought coincide with reproductive growth. Bradford (1982) reported that water deficit during flowering resulted in the reduction of grain yield and harvest index by 60 percent. It was also noted that stress at flowering inhibited pollination and resulted in sterile spikelets, the deleterious effects of water deficit stress at the flowering stage on yield could be due to reduced number of filled spikelets, reduced effective sink capacity and indirectly leads to reduced photosynthesis.

\section{Drought tolerance}

Drought tolerance has been considered as a target for breeding in order to partially compensate for the yield loss. Drought tolerance involves mechanisms that allow plants to maintain their metabolism and limit the harm caused by prolonged drought periods. These mechanisms involve different metabolic pathways in the cell, all of which results in the activation of stress response genes. These can be groups in to five categories: the osmoprotectants, ion exclusion, ion export, cell membrane modifications and antioxidant enzymes.

\section{Plant responses that help in drought tolerance}

Rice plant uses less than 5 percent of the water absorbed through roots from the soil. The rest is lost through transpiration, which helps to maintain leaf energy balance of the crop. The effect of water stress may vary with variety, growth stage of the crop, degree and duration of the stress. There may be two kinds of traits: constitutive and adaptive traits, which confer drought resistance in rice (Kamoshita et al., 2002). Constitutive traits are expressed under anaerobic, non-water stressed conditions, don't require water stress for their expression and may demonstrate variation that is subsequently modified by adaptative traits. Adaptative traits can be defined as those, such as osmotic adjustment (OA), which are expressed in response to water deficit. Identifying traits of importance in drought resistance is difficult due to the complexity of climatic variation in precipitation and evapotranspiration, the diversity of the rice hydrological environments, the relationship between soil moisture status and nutrient availability and differential plant interactions with this environment. The problem of adaptation to drought conditions in rice is complex and unique as compared with most other crops.

\section{Selection and breeding strategies for drought resistance}

Conventional breeding has been based on empirical selection for yield (Atlin and Lafitte, 2002). However, this approach is far from being optimal, since yield is quantitative trait and characterized by a low heritability and is highly affected by environmental factors (Babu et al., 2003). It is assumed that understanding the physiological and molecular basis may help target the key traits that limit yield. Such an approach may complement conventional breeding programs and hasten yield improvement (Cattivelli et al., 2008). Screening under natural drought stress conditions in the target environments is difficult because of the irregular and erratic drought response. But screening under controlled stress environments and rain-out shelters is more manageable. Selection 
response in the target population of environments under natural stress can be considered as a correlated response to selection in the managed stress environment (Venuprasad et al., 2007).

In recent studies on unselected populations of doubled haploid lines, broad-sense heritability of grain yield under reproductive-stage drought stress was comparable with that of grain yield estimated in non-stressed conditions (Atlin and Lafitte, 2002; Babu et al., 2003; Venuprasad et al., 2007). Considerable efforts have been targeted at the genetic analysis of secondary traits such as root system architecture, leaf water potential, panicle water potential, osmotic adjustment and relative water content (Jongdee et al., 2002). A suitable secondary trait is:

Genetically associated with grain yield under drought;

Highly heritable;

Stable and feasible to measure and

Not associated with yield loss under ideal growing conditions (Edmeades et al., 2001).

However, such traits rarely have high broadsense heritability like yield under drought stress and are often not highly correlated with it (Atlin and Lafitte, 2002).

\section{Molecular markers}

Recent advances in DNA marker technology together with the concept of marker assisted selection (MAS) offer solutions for improving complex traits such as drought resistance. Molecular markers linked to complex root and shoot traits would provide a new tool for selecting cultivars with greater drought resistance capacity and thereby improving rice productivity under rainfed conditions.
Molecular markers allow breeders to dissect complex traits without having to measure the phenotype, thus reducing the need for extensive field testing over time and space. Several molecular markers like Restriction Fragment Length Polymorphism (RFLP), Random Amplified Polymorphic DNA (RAPD), Amplified Fragment Length Polymorphism (AFLP), Sequence Tagged sites (STS), microsatellites or Single Sequence Length Polymorphism (SSLP), Simple Sequence Repeats (SSRs), Single Nucleotide Polymorphisms (SNPs) etc., are being used in mapping efforts. Upon identification of molecular markers tightly linked to drought resistance traits, MAS can be performed for developing high yielding cultivars suitable for water-limited environments.

\section{Marker Assisted Selection}

Molecular marker-assisted selection, often simply referred to as marker-assisted selection (MAS) involves selection of plants carrying genomic regions that are involved in the expression of traits of interest through molecular markers. With the development and availability of an array of molecular markers and dense molecular genetic maps in crop plants, MAS has become possible for traits both governed by major genes as well as quantitative trait loci (QTLs).

If the individual gene(s) or QTLs with significant influence on specific target trait(s) can be identified based on their linkage to molecular makers, the efficiency of incorporating the desired traits in elite germplasm could be greatly enhanced. While plenty of information is already available on different kinds of marker systems and genemarker associations, the practicalities of designing an MAS strategy, increasing their chance of success and efficiency have not received adequate attention till now. 
Fig.1 Different techniques for the development of a drought tolerant variety (Farooq et al., 2009)

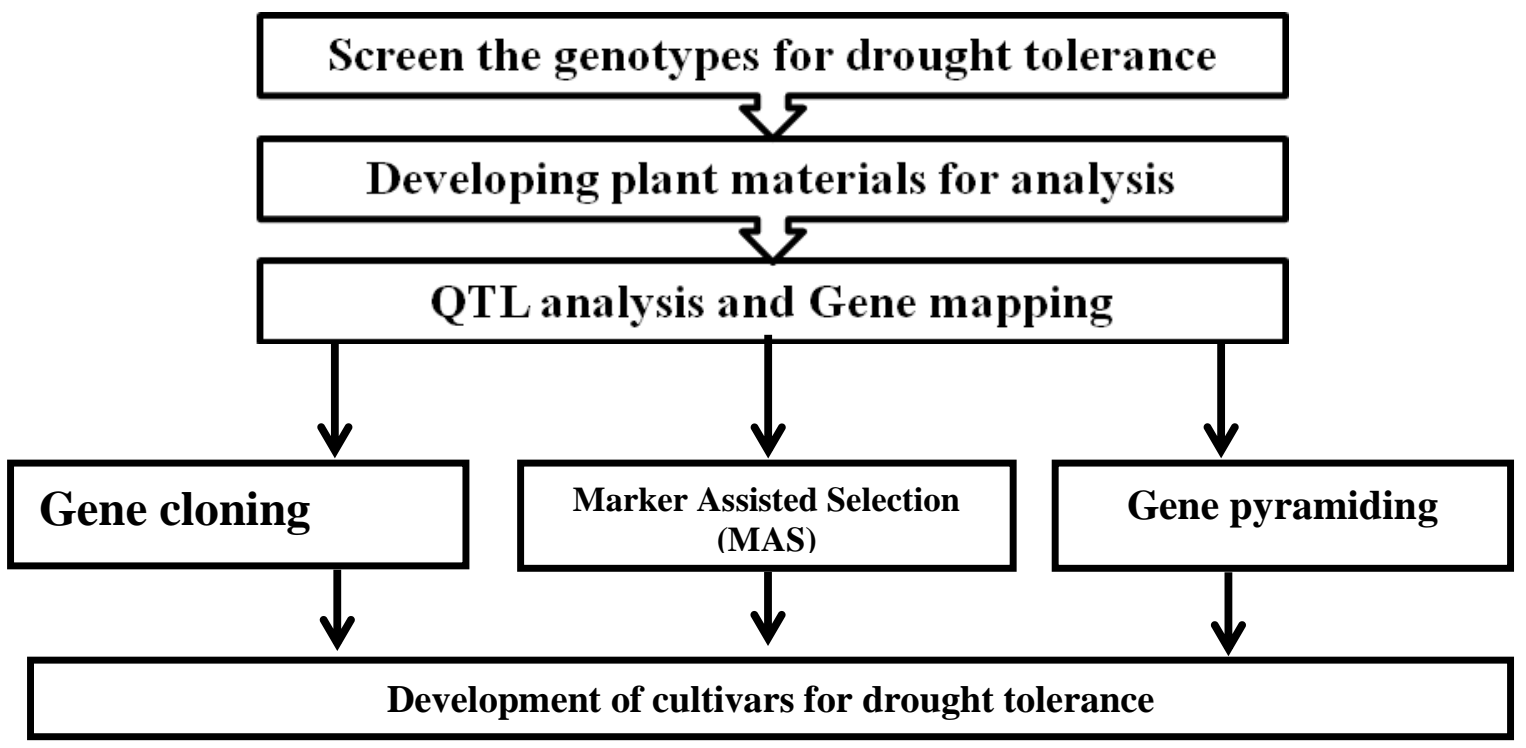

Table.1 QTLs identified for drought resistance in rice

\begin{tabular}{|c|c|c|c|c|c|c|}
\hline Parents & Population & No. Of Markers & Traits & $\begin{array}{l}\text { No. Of } \\
\text { QTLs }\end{array}$ & $\begin{array}{l}\text { Phenotypi } \\
\text { c Variance }\end{array}$ & Reference \\
\hline IR64/Azucena & $\begin{array}{c}135 \mathrm{DH} \\
\text { lines }\end{array}$ & 175(RFLP,RAPD) & $\begin{array}{c}\text { Plant height } \\
\text { No. of tillers } \\
\text { Root length } \\
\text { Root thickness } \\
\text { Total root number }\end{array}$ & $\begin{array}{c}4 \\
11 \\
5 \\
5 \\
10\end{array}$ & $\begin{array}{l}29.2 \\
25.7 \\
15.4 \\
26.7 \\
25.1\end{array}$ & $\begin{array}{c}\text { Hemamaliniet } \\
\text { al., } 2000\end{array}$ \\
\hline Bala/Azucena & $\begin{array}{c}205 \mathrm{RI} \\
\text { lines }\end{array}$ & 135(RFLP,AFLP) & $\begin{array}{l}\text { No. of penetrated } \\
\text { roots } \\
\text { Number of roots }\end{array}$ & $\begin{array}{l}7 \\
3\end{array}$ & $\begin{array}{l}16.7 \\
10.3\end{array}$ & $\begin{array}{l}\text { Price } e t \\
\text { al.,2002 }\end{array}$ \\
\hline IR64/Azucena & $\begin{array}{c}135 \mathrm{DH} \\
\text { lines }\end{array}$ & $\begin{array}{c}175 \\
\text { (RFLP,RAPD) }\end{array}$ & $\begin{array}{c}\text { Root penetration } \\
\text { index } \\
\text { Penetrated root } \\
\text { number } \\
\text { Penetrated root } \\
\text { thickness }\end{array}$ & $\begin{array}{l}2 \\
4\end{array}$ & $\begin{array}{c}9 \\
16.4\end{array}$ & $\begin{array}{l}\text { Zhenget al., } \\
\quad 2000\end{array}$ \\
\hline IR1552/Azucena & $\begin{array}{l}150 \mathrm{RI} \\
\text { lines }\end{array}$ & 207(RFLP,AFLP) & $\begin{array}{l}\text { Seminal root } \\
\text { length }\end{array}$ & 2 & 11.2 & $\begin{array}{l}\text { Zhang et } \\
\text { al.,2001 }\end{array}$ \\
\hline IR58821/IR52561 & $\begin{array}{c}166 \mathrm{RI} \\
\text { lines }\end{array}$ & 399(RFLP,AFLP) & $\begin{array}{l}\text { Penetrated root } \\
\text { number } \\
\text { Root penetration } \\
\text { index } \\
\text { Penetrated root } \\
\text { thickness } \\
\text { Total root number }\end{array}$ & $\begin{array}{l}6 \\
8 \\
2\end{array}$ & $\begin{array}{l}27.2 \\
26.2 \\
13.9 \\
12.2\end{array}$ & Ali et al.,2000 \\
\hline CT9993/IR62266 & $\begin{array}{c}154 \mathrm{DH} \\
\text { lines }\end{array}$ & 315(RFLP.AFLP) & $\begin{array}{l}\text { Penetrated root } \\
\text { thickness } \\
\text { Basal root } \\
\text { thickness } \\
\text { Root pulling } \\
\text { force }\end{array}$ & $\begin{array}{c}11 \\
6 \\
6\end{array}$ & $\begin{array}{l}31.3 \\
37.6 \\
19.9\end{array}$ & $\begin{array}{c}\text { Zhang et al., } \\
2001\end{array}$ \\
\hline
\end{tabular}




\section{Genetic linkage map in rice}

Construction of linkage map is essentially the first step in QTL mapping. Such maps allow genetic dissection of QTL, facilitate highresolution genetic mapping and positional cloning of important genes, assist in local comparisons of synteny within and across the species and provide an ordered scaffold on which complete physical maps can be assembled (Harushima et al., 1998). Recent progress in DNA markers and their linkage maps have provided an efficient tool and methods for mapping individual loci conferring not only monogenic, but also polygenic traits (Tanksley, 1997). The rice genetic map is well covered by microsatellite markers (McCouch et al., 2002) and rice researchers worldwide developed diverse mapping populations and related databases (Ware et al., 2002). A comparative genetic linkage map was constructed with rice and maize for interpreting molecular, genetic, and breeding information between these two important species and to establish a framework for ultimately connecting the genetics of all grass species (Ahn and Tanksley, 1993). A universal core genetic map (UCGM) was constructed with different rice accessions to facilitate the comparison of low resolution genetic maps with evenly distributed markers in rice (Orjuela et al., 2009). An integrated map of AFLP, SSLP and RFLP was constructed (Cho et al., 1998) with a population derived from Milyang 23 and Gihobyeo in Korean Rice Genome Research Project (KRGRP). Another kind of marker, called as Amplified Fragment Length Polymorphism (AFLP) has been described (Vos et al., 1995) and it was utilized in the genetic map construction along with previously mapped RFLP markers in rice (Causse et al., 1994; Maheswaran et al., 1997). Similarly, Random Amplified Polymorphic DNA (RAPD) markers have been integrated into the RFLP map in rice
(Subudhi and Huang, 1999). AFLP and RAPD markers offer several advantages like high frequency of polymorphism, rapidity, technical simplicity, use of fluorescence, requirement of a few nanograms of DNA, no requirement of prior information of the DNA sequence and feasibility of automation.

\section{QTL mapping for drought resistance in rice}

The availability of high density linkage maps is a valuable resource for studies that genetically dissect out the complex traits such as drought resistance. QTL mapping provides a potential tool for conducting physiological and genetics research to understand and improve drought resistance. It eases screening for traits that are difficult to quantify and influenced by environmental stimuli (Hanson et al., 1990). Marker-assisted selection using consistent-effect QTL is an efficient approach for developing appropriate aerobic rice varieties. Trait selection is another important concern in molecular breeding for aerobic traits. Wild progenitors and landraces possess valuable drought-resistance traits (Kamoshita et al., 2008). Traditional drought-tolerant donors such as Nootripathu (Gomez et al., 2010) and Dhagaddeshi (Ghimire et al., 2012) were used to identify major-effect QTLs for drought-tolerance traits. As in the case of drought, QTL for a number of physiological and morphological traits have been identified (Table 1) but they have limited implications in breeding drought-tolerant rice varieties.

In conclusion, to sum up, development of high yielding drought tolerant rice cultivars will considerably improve rice production, especially in rainfed areas. Identifying consistent QTLs for yield under stress with large effect and fine-mapping them will speed up MAB for drought tolerance in rice. QTLs with large intervals have the chance of getting undesirably linked genes; hence it is 
important to fine-map the QTLs so as to introgress the precise genomic segment of interest.

\section{References}

Ahn S., Tanksley S.D. (1993) Comparative linkage maps of the rice and maize genomes. Proc. Natl. Acad. Sci. 90:7980-7984.

Ali ML, MS Pathan, J Zhang, G Bai, S Sarkarung, HT Nguyen (2000). Mapping QTLs for root traits in a recombinant inbred population from two indica ecotype in rice. Theor. Appl. Genet. 101: 756-766.

Atlin G.N., Lafitte H.R. (2002) Markerassisted breeding versus direct selection for drought tolerance in rice, in: Saxena N.P., O'Toole J.C. (Eds.), Proc. Int. Workshopon Field Screening for Drought Tolerance in Rice, 11-14 Dec 2000, ICRISAT, Patancheru, India, and The Rockefeller Foundation, New York, p. 208.

Babu, R.C.,Nguyen, B.D., Chamarerk, V., Shanmugasundaram, P., Chezhian, P., Jeyaprakash, P (2003). Genetic analysis of drought resistance in rice by molecular markers: association between secondary traits and field performance. Crop Sci. 43, 1457-1469.

Bradford KJ, Hsiao TC (1982) Physiological responses to moderate water stress. In OL Lange, PS Nobel, CB Osmond, H Ziegler, Eds, Encyclopedia of Plant Physiology, New Series, Vol. 12b. Springer Verlag, New York, pp 263324.

Cattivelli L., Rizza F., Badeck F.W., Mazzucotelli E., Mastrangelo A.M., Francia E., Mare C., Tondelli A., Stanca A.M. (2008). Drought tolerance improvement in crop plants: An integrative view from breeding to genomics, Field Crop. Res.105, 1-14.
Causse, M. A., Fulton, T. M., Cho, Y, Ahn, S. N., Chunwongse, WU, K. (1994). Saturated molecular map of the rice genome based on an interspecific backcross population. Genetics, 138, $1251-1274$.

Chang T.T, Loresto G.C, O'Toole J.C, Armenta Solo J.C, (1982). Strategy and methodology of breeding rice for drought prone areas. In: IRRI, editor. Drought resistance in crops with emphasis to rice, Los Bafinos (Philippines), International Rice Research Institute.

Cho, Y.G. et al., (1998) Integrated map of AFLP, SSLP and RFLP markers using a recombinant inbred population of rice (Oryza sativa L.), Theor. Appl. Genet. 97,370-380.

Edmeades GO, Cooper M, Lafitte R, Zinselmeier C, Ribaut JM, Habben JE, Löffler C, Bänziger M. (2001). Abiotic stresses and staple crops. Proceedings of the Third International Crop Science Congress, Hamburg, Germany, August 18-23, 2000. CABI.

Farooq, M., Wahid, A., Ito, O., Lee, D. J., and Siddique, K. H. M (2009).Advances in drought resistance of rice. Crit. Rev. Plant Sci. 28: 199-217.

Ghimire KH, Quiatchon LA, Vikram P, Mallikarjuna Swamy BP, Dixit S, Ahmed H, Hernandez JE, Borromeo TH, Kumar A (2012). Identification and mapping of a QTL ( $q D T Y$ 1.1) with a consistent effect on grain yield under drought. Field Crops Research131, 8896.

Gomez MS, Boopathi NM, Kuma SS, Ramasubramanian $\mathrm{T}$, Chengsong $\mathrm{Z}$, JeyaprakashP, Senthil A, Babu RC (2010) Molecular mapping and location of QTLs for drought-resistance traits in indica rice (Oryza sativaL.) lines adapted to target environments. Acta Physiol Plant 32:355-364. 
Hanson, A.D., Peacock, W.J., Evans, L.T., Arntzen, C.J., Khush, G.S. (1990). Drought resistance in rice. Nature, 345, 26-27.

Harushima, Y., M Yano, A Shomura, M Sato, T Shimano, Y Kuboki, T Yamamoto, S Y Lin, B A Antonio, A Parco, H Kajiya, N Huang, K Yamamoto, Y Nagamura, N Kurata, G S Khush, and T Sasaki (1998). A high-density rice genetic linkage map with 2275 markers using a single F2 population. Genetics. 1998 Jan; 148(1):479-494.

Hemamalini G S, Shashidhar H E, Hittalmani S (2000). Molecular marker assisted tagging of morphological and physiological traits under two contrasting moisture regimes at peak vegetative stage in rice (Oryza sativa L.). Euphytica, 112: 69-78.

IRRI, World Rice Statistics (2000). International Rice Research Institute, Los Banios, Philippines. http//ricestat.irri.org.

Jongdee B., Fukai S., Cooper M. (2002) Leaf water potential and osmotic adjustment as physiological traits to improve drought tolerance in rice, Field Crop. Res.76, 153-163.

Jongdee, B. (1998). PhD Thesis, the University of Queensland, Brisbane.

Julie Orjuela, Andrea Garavito, Matthieu Bouniol (2009). A universal core genetic map for rice. Theoretical and Applied Genetics 120(3):563-72.

Kamoshita A, Babu RC, Boopathi N, Fukai S. Phenotypic and genotypic analysis of drought-resistance traits for development of rice cultivars adapted to rainfed environments. Field Crops Res. 2008; 109:1-23. doi: 10.1016/j.fcr.2008.06.010

Kamoshita, A., Wade, L.J., Ali, M.L., Pathan, M.S., Zhang, J., Sarkarung, S., Nguyen, H.T (2002). Mapping QTLs for root morphology of a rice population adapted to rainfed lowland conditions. Theoretical Applied Genetics 104, 880893.

Lanceras.J.C, Pantuwan. G, Jongdee. B, Toojinda. T (2004). Quantitaive trait loci associated with drought tolerance at reproductive stage in rice. Plant Physiol.135:384-399.

Maheswaran, M., Subudhi, P. K., Nandi, S., $\mathrm{Xu}$, J. C., Parco, A., Yang, D. C. and Huang, N. (1997). Polymorphism, distribution, and segregation of AFLP markers in a doubled haploid rice population. Theor Appl Genet, 94: 3945.

Manzanilla, D.O., Paris, T.R., Vergara, G.V., Ismail, A.M., Pandey, S., Labios, R.V., Tatlonghari, G.T., Acda, R.D., Chi, T.T.N. Duoangsila, K., Siliphouthone, I., Manikmas, M.O.A. \&Mackill, D.J (2011). Submergence risks and farmers' preferences: Implications for breeding Sub1 rice in Southeast Asia. AgriculturalSystems, 104: 335-347.

McCouch S.R., Teytelman L., Xu Y., Lobos K.B., Clare K., Walton M., Fu B., Maghirang R., Li Z., Xing Y., et al., (2002). Development and mapping of 2240 new SSR markers for rice (Oryza sativa L.). DNA Res. 2002; 9:199-207.

O'Toole JC (1982). Adaptation of rice to drought prone environments. In: Drought resistance in crops with emphasis on rice. IRRI, Los Baños, Philippines, 195-213.

Price AH, Steele KA, Moore BJ, Jones RGW (2002) Upland rice grown in soil-filled chambers and exposed to contrasting water-deficit regimes: II. Mapping quantitative trait loci for root morphology and distribution. Field Crops Res.76: 25-43.

Production and Consumption of rice in India, Rice Commodity Profile, 2017

Subudhi P.K and Huang N. (1999).RAPD mapping in a doubled haploid 
population of rice (Oryza sativa L.) Hereditas, 130: 2-9.

Tanksley, S. D. and McCouch, S. R (1997). Seed banks and molecular maps: unblocking genetic potential from the wild. Science, 1997, 277, 1063-1066.

Venuprasad R., Lafitte H.R., Atlin G.N. (2007) Response to direct selection for grain yield under drought stress in rice, Crop Sci. 47, 285-293.

Vos, P., Hogers, R., Bleeker, M., Reijans, M., van de Lee, T., Hornes, M., Frijters, A., Pot, J., Peleman, J., Kuiper, M., Zabeau, M (1995). AFLP: a new technique for DNA fingerprinting. Nucleic Acids Res. 11, 4407-4414.

Ware, D., Jaiswal, P., Ni, J. (2002), Gramene:

A Resource for Comparative Grass Genomics, Nucl. Acids. Res., 30, 103 105.

Wassmann, R., Jagadish, S.V.K., Heuer, S., Ismail, A., Redoña, E., Serraj, R.,
Singh, R.K., Howell, G., Pathak, H. and Sumfleth, K. (2009). Climate change affecting rice production: the physiological and agronomic basis for possible adaptation strategies. Adv. Agron. 101: 59-122.

Zhang J, Zheng HG, Aarti A, Pantuwan G, Nguyen TT, Tripathy JN, Sarial AK, Robin S, Babu RC, Nguyen BD, et al., (2001) Locating genomic regions associated with components of drought resistance in rice: comparative mapping within and across species. Theor Appl Genet 103:19-29.

Zheng H.G., Babu R.C., Pathan M.S., Ali L., Huang N., Courtois B. and Nguyen H.T. (2000). Quantitative trait loci for rootpenetration ability and root thickness in rice: comparison of genetic backgrounds. Genome 43: 53-61.

\section{How to cite this article:}

Helan Baby Thomas, Thriveni Vangapandu, Bharathi Ayyenar and Reena Sellamuthu. 2017. Identification and Mapping of Qtls for Drought Resistance in Rice. Int.J.Curr.Microbiol.App.Sci. 6(7): 1703-1710. doi: https://doi.org/10.20546/ijcmas.2017.607.205 